\title{
Effects of Aggressive Environment on the Durability of Concrete Produced with Binary and Ternary Blend Cement
}

\author{
${ }^{1 a}$ Gana Matthew Sunday, ${ }^{2 b}$ Erasmus P. D. and ${ }^{1 c}$ Shehu I. A, \\ 1. Department of building, Technology Federal Polytechnic, Bida. Nigeria \\ 2.Department of building, University of Jos, Nigeria
}

\begin{abstract}
This study investigates the durability of concrete made with ordinary Portland cement (OPC), Bambara nut shell ash (BSA) and Groundnut shell ash (GSA) in subjection to aggressive environments containing $20 \%$ of Sulphuric acid $\left(\mathrm{H}_{2} \mathrm{SO}_{4}\right)$ and Magnesium sulphate $\left(\mathrm{MgSO}_{4}\right)$ solution each, to investigate durability studies under different aggressive chemical environment with particular reference to the effect of acid. When concrete is exposed to aggressive environment, the environment degredate the concrete, the setting time and hardening characteristic of cement are affected, the reinforcements are degradated thereby lowering the durability and bearing capacity of the concrete. However, Pozzolanas such as Groundnut shell ash (GSA) and Bambara nut shell ash (BSA) have been observed and subjected to the aggressive environment to evaluate their effects in aggressive environments. The compressive strength was obtained at curing ages of 28,56 and 90 days respectively. The ternary and binary blends were both subjected to durability studies under different aggressive chemical environments with particular reference to the effect of Sulphuric acid $\left(\mathrm{H}_{2} \mathrm{SO}_{4}\right)$ and Magnesium Sulfate $\left(\mathrm{MgSO}_{4}\right)$ the effects were then compared with ordinary Portland cement (OPC). The cubes were immersed in different solutions for different time duration of 28,56 and 90 days and then the specimens were evaluated in terms of physical appearance, compressive strength, sorptivity, water absorption, and other physicochemical and mineralogical content. It was observed that concrete specimens containing GSA and BSA as excellent resstance in $\mathrm{MgSO}_{4}$ solution as compare to those of OPC only. A somewhat similar result was obtained in those immersed in acid solution It is well known that mechanisms of attack by acid and Magnessium sulfates are different in both the case (GSA, BSA and OPC), The conventional concretes are generally not resistant to prolonged exposure to very high concentrations of these solutions because decalcification of $\mathbf{C}$ $\mathrm{S}-\mathrm{H}$ will occur. The effect on compressive strength and other parameters including structural and mineralogical changes was further evaluated and confirmed with the help of $\mathrm{X}$-ray fluorescence study (XRF). The finding revealed that the deterioration rate of the binary (OPC/GSA) concrete subjected to $20 \% \mathrm{H}_{2} \mathrm{SO}_{4}$ at $0 \%, 10 \%, 20 \%$ and $30 \%$ part replacements cement with GSA and BSA was less severed among every other attack experienced on concretes throughout the study. Adjudged as not having satisfied the compressive strength requirement of grade 25 concrete, the utilization of concrete produced with part replacement of ternary (GSA, BSA and OPC) contents is thus recommended for producing concrete with compressive strength not exceeding $20 \mathrm{~N} / \mathrm{mm}^{2}$ at a replacement level not greater than $30 \%$.
\end{abstract}

Keywords: Aggressive chemical environment, Acid attack, Compressive Strength, Durability, Sulfate resistance, binary, ternary.

\section{INTRODUCTION}

Cementitious materials mostly naturally or artificially occurring can be used partly or wholly to replace Portland cement in concrete or mortar to reduce their negative influence in our immediate environment. According to Venkata and Mahindrkar [1] the influence of aggressive environment on the durability behavior of concrete on aggressive environment which posses negative effect on construction material can be overcome through the application cementitious or pozzolan material. This study is therefore of significance interest. Aggressive environment can be defined as environment which involves hazardous substances which degredate concrete and reinforcements thereby lowering the resistance and load bearing capacity of the concrete products. The aggressive environments affecting the setting and hardening characteristics of cement are either available in nature or produced from industries and automobile activities

Chemicals such as sulphuric and nitric acid have much negative influence on the basic properties of cement. Similarly, pollution due to unplanned disposal of industrial and urban wastes on earth surface brings about the presence of acids, bases and salts. Thus air, water and soil pollution contribute to increased chemical concentrations on environments. Amongst the various properties of cement which are of interest, the setting times and strength are of basic importance [2]. Most pozzolans are used individually, but blends of two or more different pozzolans can be used to take advantage of the characteristics each pozzolan offers [3]. This paper present experimental result on the durability of concrete produced with binary and ternary blend using Bamabara and ground nut shell ash as cementitious materials in aggressive environment. 


\section{MATERIALS AND TEST METHOD}

\subsection{Material}

Tests were conducted to assess the properties of concrete made by partial replacement of cement with bamabara and ground nut shell ash in tenary and binary blend form. The constituent materials include; cement, fine and coarse aggregate, Bambara nut shell ash (BSA), Groundnut shell ash (GSA), Magnessium sulphite $\left(\mathrm{MgSO}_{4}\right)$, supharic $\operatorname{acid}\left(\mathrm{H}_{2} \mathrm{SO}_{4}\right)$, Silicon tube sealant and water were all sourced and used. The groundnut shell ash (GSA) and Bambara groundnut shell ash used for this research work was sourced from farmers within Bauchi, Gombe and Niger State, Nigeria. The shells were burn to ash at temperature of $600^{\circ} \mathrm{C}$ using kiln at ceramic firing section in Department of industrial design, school of Environmental science Abubakar Tafawa Balewa University Bauchi (ATBU) in accordance to BS EN 197, Part 1[4]. The ash was allowed to cool and then ground to very fine particle and sieve with $150 \mu \mathrm{m}$ sieve. Laboratory tests such as sieve analysis, Bulk density were carried out at Building Department Laboratory, University of Jos, Plateau State, Nigeria in order to ascertain the general specifications and physical properties.

\subsection{Mix proportion}

The mix proportion of the concrete is shown in the Tables 1 and 2 for both binary and ternary blended cement. The summary of quantities of material required per $1 \mathrm{~m}^{3}$ of concrete for OPC, GSA and BSA content was replaced at part replacement levels of $0 \%, 10 \%$, $20 \%$ and $30 \%$. These replacement levels was adopted based on previous research finding carried out by Alabadan, et al [5-6]. Concrete grade of $25 \mathrm{~N} / \mathrm{mm}^{2}$ was designed using the method of Department of Environmental (DOE) to BS 8110: part 2 [7].

Table 1: Mix proportion of Binary concrete

\begin{tabular}{|l|l|l|l|l|l|l|l|}
\hline & & \multicolumn{3}{|c|}{ GSA } & \multicolumn{3}{c|}{ BSA } \\
\hline Materials & Control & 10 & 20 & 30 & 10 & 20 & 30 \\
\hline $\begin{array}{l}\text { OPC } \\
\left(\mathrm{kg} / \mathrm{m}^{3}\right)\end{array}$ & 452 & 407 & 367 & 316 & 407 & 367 & 316 \\
\hline GSA & 0 & 45 & 90 & 136 & 0 & 0 & 0 \\
\hline BSA & 0 & 0 & 0 & 0 & 45 & 90 & 136 \\
\hline $\begin{array}{l}\text { Fine agg } \\
\left(\mathrm{kg} / \mathrm{m}^{3}\right)\end{array}$ & 539 & 539 & 539 & 539 & 539 & 539 & 539 \\
\hline $\begin{array}{l}\text { Coarse } \\
\text { agg } \\
\left(\mathrm{kg} / \mathrm{m}^{3}\right)\end{array}$ & 1259 & 1259 & 1259 & 1259 & 1259 & 1259 & 1259 \\
\hline & 217 & 217 & 217 & 217 & 217 & 217 & 217 \\
$\begin{array}{l}\text { Water } \\
\mathrm{kg} / \mathrm{m}^{3}\end{array}$ & & & & & & & \\
\hline
\end{tabular}

Table 2: Mix proportion of Ternary concrete

\begin{tabular}{|c|c|c|c|c|}
\hline & & \multicolumn{3}{|c|}{ OPC/GSA/BSA } \\
\hline Materials & Control & 10 & 20 & 30 \\
\hline $\begin{array}{l}\text { OPC } \\
(\mathrm{kg} / \mathrm{m} 3)\end{array}$ & 452 & 217 & 217 & 217 \\
\hline GSA & 0 & 45 & 90 & 136 \\
\hline BSA & 0 & 136 & 90 & 45 \\
\hline $\begin{array}{l}\text { Fine agg } \\
(\mathrm{kg} / \mathrm{m} 3)\end{array}$ & 539 & 539 & 539 & 539 \\
\hline
\end{tabular}

\begin{tabular}{|l|l|l|l|l|}
\hline $\begin{array}{l}\text { Coarse } \\
(\mathrm{kg} / \mathrm{m} 3)\end{array}$ & 259 & 1259 & 1259 & 1259 \\
\hline $\begin{array}{l}\text { Water } \\
(\mathrm{kg} / \mathrm{m} 3)\end{array}$ & 217 & 217 & 217 & 217 \\
\hline
\end{tabular}

\subsection{Preparation of specimens and Testing of Concrete}

The test was performed to assess the physical characteristic and response of concrete to attack in sulphate and acid solution. Concrete cubes specimen were cast and assessment on aggressive environment were made in terms of weight and strength lost as well as visual observation.

The Laboratory experiment was performed at the Building Department Laboratory, University of Jos, Plateau State. A total of 372 cubes were cast using 100 x 100 x $100 \mathrm{~mm}$ moulds and were vibrated for 1 minutes on a vibrating table. All cubes were demoulded after 24 hours and then cured in water containing $\mathrm{MgSO}_{4}$ and $\mathrm{H}_{2} \mathrm{SO}_{4}$ solutions for a period of 28, 56 and 90 days. Physical properties such as weight, density and visual observation and concrete deterioration test was carried out as well as mechanical properties such as compressive strength, water absorption and Energy dispersive amd X-ray diffraction test were carried out.

\section{RESULTS AND DISCUSSION}

\subsection{Physical and chemical properties of BSA, GSA and $\mathrm{OPC}$}

The physical and chemical properties of ordinary Portland cement (OPC), groundnut shell ash (GSA) and Bambara nut shell ash (BSA) are presented in Table 3. It can be seen that GSA contain high amount of silica oxide $\left(\mathrm{SiO}_{2}\right)$ of $74.52 \%$, with $33,3 \%$ of $\mathrm{AL}_{2} \mathrm{O}_{3}$ and $0.25 \%$ of $\mathrm{Fe}_{2} \mathrm{O}_{3}$, making a total of approximately $79 \%$. This total demonstrates that GSA satisfies the ASTM requirement of pozzolan. Although BSA possess similar chemical composition with GSA but it has a low content of $\mathrm{SiO}_{3}$ of $33.36 \%$ as compared to GSA and Portland cement and therefore does not satisfy the pozzolaic requirement.

The presence of Silica oxide in high quantity gives rise to the pozzolanic reaction when ordinary Portland cement (free lime) reacts with water $\mathrm{H}_{2} \mathrm{O}$, it produces calcium silicate hydrate $(\mathrm{C}-\mathrm{S}-\mathrm{H})$ gel which is beneficial to strength development of both GSA and BSA. The physical properties reveal that the specific gravity of cement is 3.15 as indicate in Table 4, while those of BSA and GSA are lower than that of OPC, yet they are within the range specified for pozzolan materials.

Bulk density for fine aggregate is $1652 \mathrm{~kg} / \mathrm{m}^{3}$, coarse aggregate is $1631 \mathrm{~kg} / \mathrm{m}^{3}$, while those of Bambara nut shell ash and groundnut shell ash are $652 \mathrm{~kg} / \mathrm{m}^{3}$ and $531 \mathrm{~kg} / \mathrm{m}^{3}$ respectively. The bulk densities of the pozzolan materials are generally found to be lower than that of OPC. 
Table 3 Chemical composition of OPC, GSA and BSA

\begin{tabular}{|c|c|c|c|}
\hline Constituent & $\begin{array}{l}\text { \% Comp } \\
\text { (OPC) * }\end{array}$ & $\begin{array}{l}\% \text { Comp } \\
\text { (GSA) ** }\end{array}$ & $\begin{array}{l}\text { \%Comp (BSA) } \\
* * *\end{array}$ \\
\hline $\begin{array}{l}\text { Ferrous } \\
\text { oxide }\left(\mathrm{Fe}_{2} \mathrm{O}_{3}\right)\end{array}$ & 4.60 & 0.25 & 2,16 \\
\hline $\begin{array}{l}\text { Silica } \\
\text { dioxide } \\
\left(\mathrm{SiO}_{2}\right)\end{array}$ & 22.0 & 74.52 & 33.36 \\
\hline $\begin{array}{l}\text { Calcium } \\
\text { oxide }(\mathrm{CaO})\end{array}$ & 62.0 & 0.50 & 1.91 \\
\hline $\begin{array}{l}\text { Aluminiumo } \\
\text { xde }\left(\mathrm{AL}_{2} \mathrm{O}_{2}\right)\end{array}$ & 5.02 & 3.23 & 1.75 \\
\hline $\begin{array}{l}\text { Magnesium } \\
\text { oxide (MgO) }\end{array}$ & 2.06 & 2.25 & 4.72 \\
\hline $\begin{array}{l}\text { Sodium } \\
\text { oxide }\left(\mathrm{Na}_{2} \mathrm{O}\right)\end{array}$ & 0.19 & 0.39 & 9.30 \\
\hline $\begin{array}{l}\text { Potassium } \\
\text { oxide }\left(\mathrm{K}_{2} \mathrm{O}\right)\end{array}$ & 0.40 & 1.40 & 16.18 \\
\hline $\begin{array}{l}\text { Sulphate } \\
\left(\mathrm{SO}_{3^{-}}\right)\end{array}$ & 1.43 & 0.09 & $6.40 \%$ \\
\hline $\begin{array}{l}\text { Loss } \\
\text { Ignition } \\
\text { (L.O.I) }\end{array}$ & $\begin{array}{c}11.1 \\
7\end{array}$ & & - \\
\hline
\end{tabular}

Source: $*[4], * *[6]$ and $* * *[1]$

Table 4. Physical Properties of Aggregate and BSA/GSA

\begin{tabular}{|l|l|l|l|l|l|}
\hline $\begin{array}{l}\text { Physical } \\
\text { Properties }\end{array}$ & OPC & $\begin{array}{l}\text { Fine } \\
\text { Agg }\end{array}$ & $\begin{array}{l}\text { Coarse } \\
\text { Agg }\end{array}$ & BSA & GSA \\
\hline $\begin{array}{l}\text { Maximum } \\
\text { Sieve Size } \\
(\mathrm{mm})\end{array}$ & & 4.75 & 12.5 & 4.75 & 4.75 \\
\hline $\begin{array}{l}\text { Specific } \\
\text { Gravity }\end{array}$ & 3.15 & 2.40 & 2.71 & 2.48 & 2.26 \\
\hline $\begin{array}{l}\text { Bulk Density } \\
\left(\mathrm{kg} / \mathrm{m}^{3}\right)\end{array}$ & & 1652 & 1631 & 652 & 531 \\
\hline
\end{tabular}

\section{Effect of magnesium sulphate on concrete containing groundnut shell ash}

Effect of Magnesium sulphate $\left(\mathrm{MgSO}_{4}\right)$ and sulphuric acid $\left(\mathrm{H}_{2} \mathrm{SO}_{4}\right)$ on groundnut shell ash (GSA) at 28, 56 and 90-days of hydration is tabulated in the form of performance scale as shown in Table 5 as suggested in Tondon (8) and Kolapo and Opeyemi (2). Deterioration due to magnesium sulphate is shown in figure 1, while figure 2 shows the effect of $\mathrm{Mg}_{2} \mathrm{SO}_{4}$ as expressed in the performance scale. The scale demonstrates the level of deterioration otherwise known as performance scale in the other of 1-6. As shown in Table 5.

Table 5.The $\mathrm{pH}$ value and performance scale of a concrete

\begin{tabular}{|l|l|l|l|}
\hline S/NO & $\begin{array}{l}\text { Performance } \\
\text { Scale }\end{array}$ & $\mathrm{pH}$ Value & $\begin{array}{l}\text { Acid Severity } \\
\text { Attack }\end{array}$ \\
\hline 1 & 0 & - & No attack \\
\hline 2 & 1 & - & Slight attack \\
\hline 3 & 2 & 7 & Neutral \\
\hline 4 & 3 & 6.5 & Moderate \\
\hline 5 & 4 & 5.5 & Severe \\
\hline 6 & 5 & 4.5 & Very severe \\
\hline 7 & 6 & - & Partial disintegration \\
\hline
\end{tabular}

(Tondoon, 2011; Kolapo and Opeyemi, 2012)

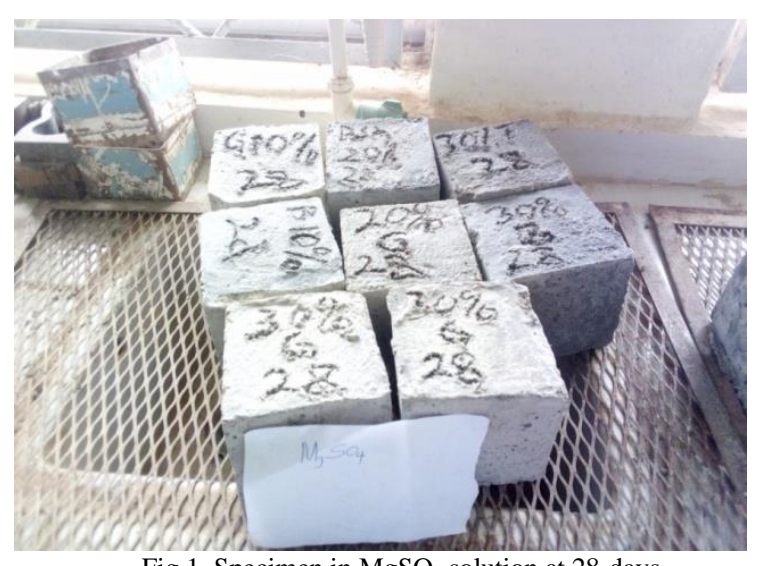

Fig 1. Specimen in $\mathrm{MgSO}_{4}$ solution at 28-days

The control concrete (ie) OPC ( $0 \%)$ concrete experienced moderate attack when exposed to $20 \%$ concentration of Magnesium sulphate at 28-days. The attack was not severe compared to part replacement of GSA subjected to the same amount of acid. The addition of $10 \%$ and $20 \%$ part replacements of groundnut shell ash (GSA) based binary blended concrete on $\mathrm{MgSO}_{4}$ resulted into a very severe attack at 28-days of hydration. However, the attack reduces to severe with $30 \%$ replacement. At 56-days concrete exposure to $\mathrm{MgSO}_{4}$, the concrete experienced severe attack (4) all through the part replacements. The severity ranges between 4.5 and $5.5 \mathrm{PH}$ value on $0 \%, 10 \%, 20 \%$ and $30 \%$ part replacements and very severe on $30 \%$ part replacement of GSA. During 90days of hydration, the attack of $\mathrm{MgSO}_{4}$ on GSA was moderate throughout the part replacements, this in turn indicates that the effect of $\mathrm{MgSO}_{4}$ reduces as the age increases as can be seen in figure 1 .

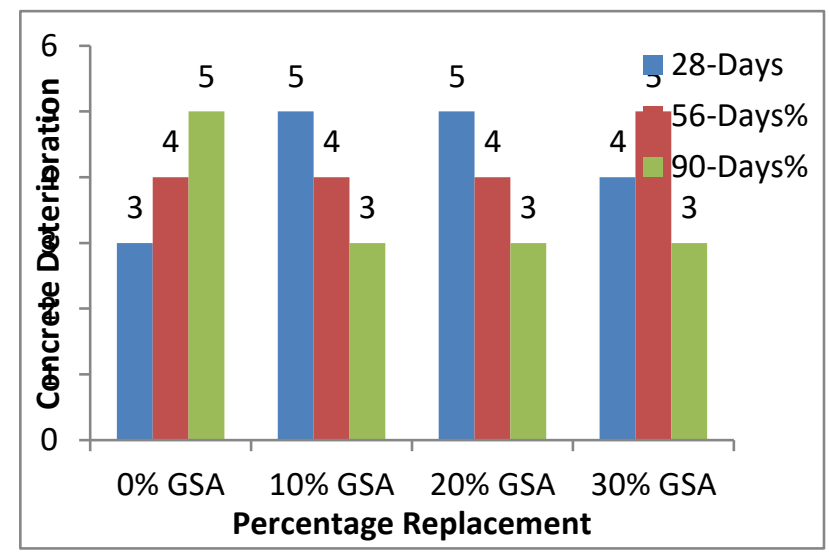

Fig 2: Concrete Deterioration due to Replacement of GSA in $\mathrm{MgSO}_{4}$

\section{$3.3 \quad$ Effect of sulphuric acid on binary and ternary concrete at 28, 56 and 90days of hydration}

The effect of $20 \%$ sulphuric acid on compressive strength of groundnut shell ash (GSA) for 0\%, 10\% 20\% and 30\% cubes for 28, 56 and 90-day hydration periods were compared are shown in figure 3 , and performance index shown in figure 4 . The concrete deterioration rate ranges from severe to very severed attack (4-5) at $0 \%, 10 \%, 20 \%$ and 30\% percentage replacements all through the age, The concrete deterioration observed was connected to deficiency of calcium hydroxide $(\mathrm{CaO})$ in groundnut shell 
ash (BSA). The BSA cubes exposed to sulphuric acid undergoes white layer of gypsum crystals on the surface of the cubes at 28, grey colour at 56 and grey-dark colour at 90days as can be seen in Fig 2. The deterioration rate of the binary (OPC/GSA) concrete subjected to $\mathrm{H}_{2} \mathrm{SO}_{4}$ at $0 \%$, $10 \%, 20 \%$ and $30 \%$ was the most severed among every other attack experienced on concretes throughout the study. The compressive strength of the control concrete and concrete made with OPC/BSA were found low due to the effect of acid which react with $\mathrm{CaO}$ in the Portland cement which promote deterioration in the form of crystallization.

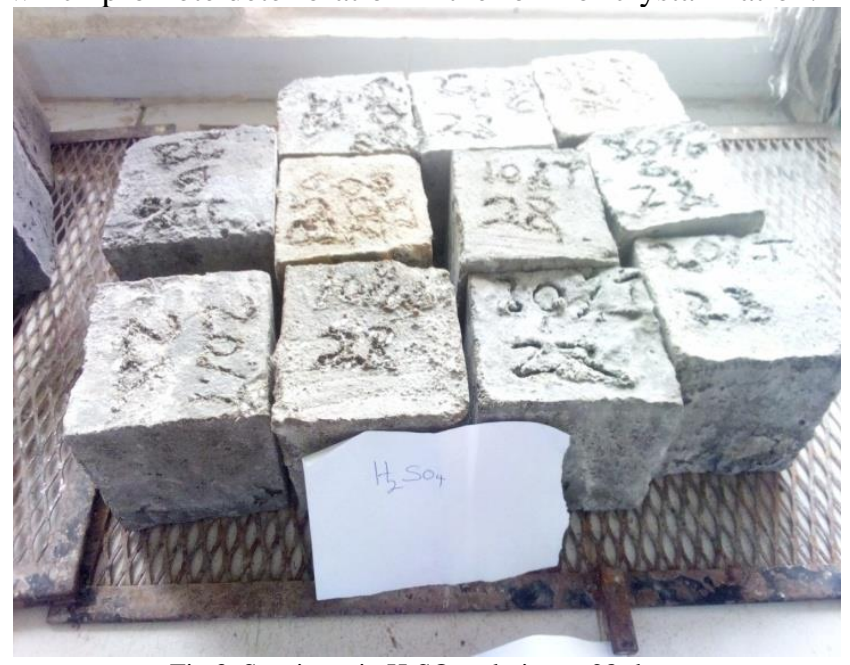

Fig 3. Specimen in $\mathrm{H}_{2} \mathrm{SO}_{4}$ solution at 28-days

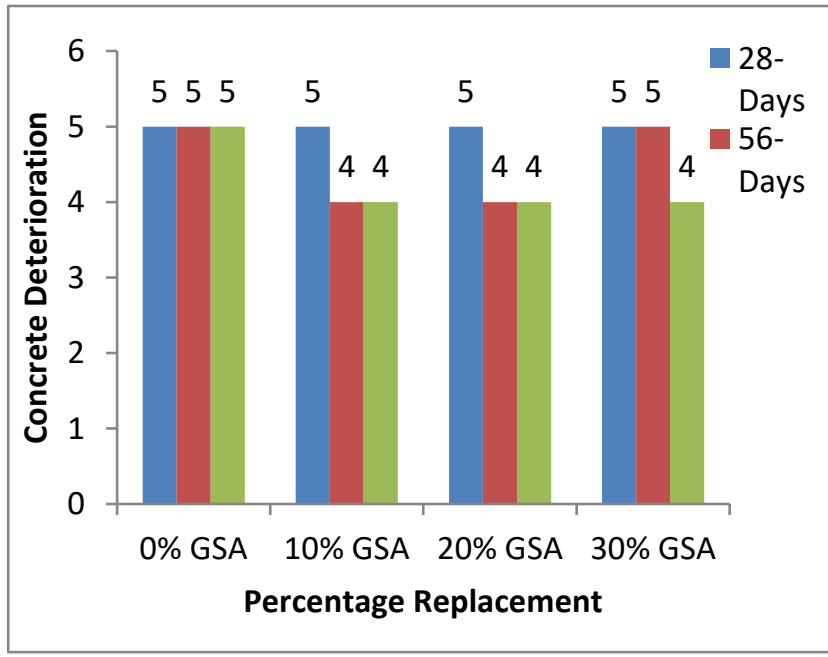

Fig 4: Concrete Deterioration due to Replacement of GSA in $\mathrm{H}_{2} \mathrm{SO}_{4}$

\subsection{Compressive strength of ternary concrete at 28, 56 and 90-days hydration periods}

The compressive strength results for $10 \%, 20 \%$ and $30 \%$ ternaries (OPC/GSA/BSA) replacement at 28days, 56-days and 90-day hydration periods as shown in Figure 5. The compressive strength values were $30 \mathrm{~N} / \mathrm{mm}^{2}, \quad 24.50 \mathrm{~N} / \mathrm{mm}^{2}$ and $28.00 \mathrm{~N} / \mathrm{mm}^{2}$ where obtained for the periods of 28, 56 and 90 days respectively. This increment in compressive strength may be attributed to the presence of silicon, iron and aluminum oxide which react with the calcium oxide present in the Portland cement.
From the graph it can be seen that the strength reduces as the period of immersion in aggressive environment increases. Although, the strengths after 90days immersion are generally below the design strength of $25 \mathrm{~N} / \mathrm{mm} 2$, yet the values obtained can favorably adopted for non load bearing structures

The compressive strength increased throughout the immersion period of $10 \%$ part replacement of cement. The increment may due to the formation of dicalcium and tricalcium silicates The compressive strength of ternaries as shown in the same table shows an appreciable increase on compressive strength as $28.20 \mathrm{~N} / \mathrm{mm}^{2}, 34.67 \mathrm{~N} / \mathrm{mm}^{2}$ and $28.70 \mathrm{~N} / \mathrm{mm}^{2}$ at 28,56 and 90-day hydration periods

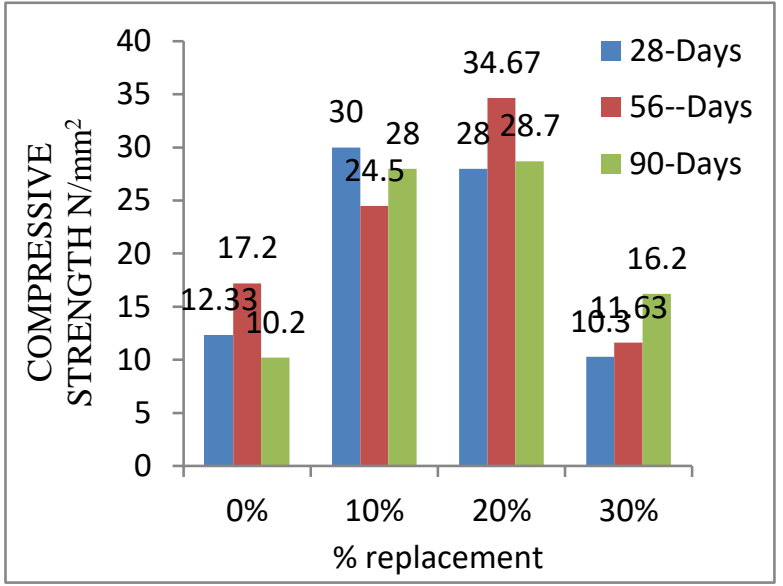

Fig 5. Compressive strength of ternary concrete at 28,56 , and 90 -days

\section{CONCLUSSION}

The results of the test carried out revealed that maximum compressive strength achieved for $10 \%$ ternary blend at 28,56 and 90day hydration periods is $30.00 \mathrm{~N} / \mathrm{mm}^{2}, 24.50 \mathrm{~N} / \mathrm{mm}^{2}$ and $28.00 \mathrm{~N} / \mathrm{mm}^{2}$ at 28,56 and 90-day hydration periods. Similarly, the compressive strength achieved for $20 \%$ ternary blend at 28, 56 and 90-day hydration periods is $28.20 \mathrm{~N} / \mathrm{mm}^{2}$, $34.67 \mathrm{~N} / \mathrm{mm}^{2}$ and $28.70 \mathrm{~N} / \mathrm{mm}^{2}$, the result therefore show that the maximum compressive strength achieved is $34.67 \mathrm{~N} / \mathrm{mm}^{2}$ at 56 -days hydration periods, The percentage increase in compressive Strength of ternary blended concrete is found to be higher at all ages.

It was observed that $\mathrm{SiO}_{2}$ is sufficient in both GSA, as a result, it impact strength to the cement due to the formation of dicalcium and tricalcium silicates. It was also observed that the combination of $10 \%$ at 28 -days, and $30 \%$ at 56-days binary OPC/BSA subjected to $\mathrm{MgSO}_{4}$ gave the least compressive strength in all cubes; this may be attributed to the deficiency of $\mathrm{SiO}_{2}, \mathrm{Fe}_{2} \mathrm{O}_{3}$ in BSA and its high vulnerability to acid attack. The study also shows that the $\mathrm{MgSO}_{4}$ has less effect on binary and ternary blend Groundnut shell ash concretes at all ages. It was however noted that the subjection of Bambara nut shell ash to $\left(\mathrm{H}_{2} \mathrm{SO}_{4}\right.$ resulted into the 
lowest compressive strength, which indicates that the acid have much effect on BSA concrete than GSA. The utilization of ternary as a pozzolana is considered feasible, having met the requirements of the properties of pozzolana. The conclusion is therefore reached that ternary blend concrete could be of great advantage in performance of concrete in aggressive environment.

\section{ACKNOLEDGEMENT}

The authors thank almighty God for making it possible to get this far. Our appreciation goes to the technical staff of the Building Laboratory University of Jos Plateau state and Civil Engineering department Federal Polytechnic Bida Niger state in conducting the experimental work. We appreciate the tetfund for their financial support throughout the project.

\section{REFERENCES}

[1] Venkata, R. V., \&Mahindrkar A. B. (2017). Impact of aggressive environment on concrete- a review. International Journal of Civil Engineering and Technology (IJCIET)., 5(9), 778-788.

[2] Kolapo O. O and Opeyemi J., (2012): Effect of Nitric Acid Concentration on the Compressive Strength of Laterized Concrete. Civil and Environmental Research 2(10): 48-57.

[3] Datok, E. P., Molwus J. J., \&Sule N. (2010). The production of concrete utilizing Ordinary Portland cement being partially replaced with groundnut shell ash. Word congress on Housing Standard Spain.

[4] BS EN 197, part 1. (2000). Test for geometrical properties of aggregates part 1 .

[5] Determination of particle size distribution sieving method.

[6] Alabadan, B. A., Njoku C. F., \& Yusuf M. O. (2006). The Potentials of Groundnut Shell Ash as Concrete Admixture, Agricultural Engineering International. The CIGR Journal, 5(12), $1-8$.

[7] Alabadan, B. A., Olutoye M. A., Abolarin M. A., \&Zakariya M. (2005). Partial Replacement of Ordinary Portland Cement (OPC) with Bambara nut Shell Ash (BSA) in Concrete. Journal of Practices and Technologies. (6), 43-48.

[8] British Standards Institution, BS 8110: Tart 2(1985): Structural Use of Concrete: Code of Practice for Design and Construction. London, BSI.

[9] Tondon, G. (2011). Sal Institute of Technology and Engineering Research 